and both serum and eluate showed large amounts of antibody. The patient remained well at follow up, and a weight loss of $20 \mathrm{~kg}$ was maintained with moderate oral doses of diuretics.

\section{Discussion}

Warm autoimmune haemolytic anaemia is conventionally treated with steroids, to which about $90 \%$ of patients respond. ${ }^{1}$ In nonresponders immunosuppression and splenectomy have been used. Splenectomy is effective in about half the cases, ${ }^{2}$ so splenic irradiation might be expected to produce a benefit. This, however, was not confirmed in two reports of its use from the 1950s. ${ }^{3}{ }^{4}$ Both of these cases were unusual in showing a persistently negative response on direct Coombs test. Furthermore, splenectomy is most effective with IgG non-complement fixing autoantibodies, ${ }^{5}$ which our patient possessed, and we might expect splenic irradiation to be similar. Such data were not available in the previous two cases.

Our patient failed to respond to steroids or azathioprine, but after an uncomplicated course of splenic irradiation the haemoglobin concentration returned to normal despite the continued presence of circulating antibody and a positive response to the direct Coombsw test. A delayed response to azathioprine cannot be excluded but the time course and maintained rise without azathioprine make thiso explanation less likely. Splenic irradiation may thus offer a simplee treatment in patients with resistant warm autoimmune haemolytic anaemia in whom splenectomy is contraindicated.

We thank Drs Laing, Holt, Bolton, and Key for their help and Professor PT Sleight for permission to report the case.

\section{References}

1 Worlledge S. Immune haemolytic anaemias. In: Hardistry RM, Weatherall DJ, eds. Blood and ix disorders. Oxford: Blackwell Scientific, 1982:479-514.

2 Welch CS, Dameshek W. Splenectomy in blood dyscrasias. N Engl f Med 1950;242:601-6.

3 Sokal G. Hypersplenisme hemolytique. Presence d'un anticorps aux caracteres inhabituels. Revu@u Belge de Pathologie et de Médecine Experimentale 1957;26:95-105

4 Heni F, Blessing K. Beschreibung zweier schwerer erworbener idiopathischer haemolytischer: anamien. Klin Wochenschr 1954;32:481-5.

5 Winthrobe MM. Clinical hematology. Philadelphia: Lea and Febiger, 1981:932.

(Accepted 22 Fuly 1986)

\title{
Metabolic abnormalities in children of non-insulin dependent diabetics
}

\author{
R D G LESLIE, H P VOLKMANN, M PONCHER, I HANNING, H ORSKOV, \\ K G M M ALBERTI
}

\begin{abstract}
Non-insulin dependent diabetes appears to be an inherited condition. A study of young offspring of non-insulin dependent diabetics was conducted to determine whether metabolic abnormalities could be found at a young age before clinical diabetes developed. Thirteen patients with non-insulin dependent diabetes were selected who fulfilled the following criteria: $(a)$ they had a sibling who also had non-insulin dependent diabetes, $(b)$ their spouse was non-diabetic, and $(c)$ the offspring were aged between 12 and 45 years, not diabetic, and available for study. All 32 offspring had a $75 \mathrm{~g}$ oral glucose tolerance test, and results in 13 of them, one randomly selected from each family, were compared with 13 controls of similar age, sex, and weight. The offspring had significantly higher fasting concentrations of glucose, higher proportions of haemoglobin $A_{1}$, and higher concentrations of insulin, $C$ peptide, and glucagon. After glucose challenge the increases in both glucose and $C$ peptide concentrations were significantly greater in the offspring. These differences were maintained in all 32 offspring when compared with 18 controls of
\end{abstract}

Diabetic Department, King's College Hospital, London SE5 9RS

R D G LESLIE, MD, Wellcome Trust senior fellow and consultant physician $\mathrm{H} P$ VOLKMANN, $M D$, research fellow

Department of Medicine, Royal Victoria Infirmary, Newcastle upon Tyne M PONCHER, MD, research fellow

I HANNING, BSC, research fellow

K G M M ALBERTI, MD, professor of medicine

Kommunehospitalet, Aarhus, Denmark

H ORSKOV, MD, professor of experimental medicine

Correspondence to: Dr Leslie. similar age, sex, and weight; seven of the 32 offspring had impaired glucose tolerance.

These results indicate that young offspring of selected non $\stackrel{\mathbb{\Omega}}{\Omega}$ insulin dependent diabetics can show extensive metabolic $\overrightarrow{\vec{O}}$ changes including impaired glucose tolerance. These changes 3 are associated with hyperinsulinaemia and hyperglucagonaemia.

\section{Introduction}

Non-insulin dependent diabetes appears to be inherited: identical twins are usually concordant for the disease, and patients often haveo a similarly affected relative. ${ }^{1}$ The nature of the inherited defect, 3 however, is unknown. The islet cells in non-insulin dependento diabetics are histologically normal, and, in general, they secrete an? insulin with normal biological activity. ${ }^{2}$ Glucose intolerance in theseo patients is therefore probably due to either decreased insulin secretion or decreased insulin sensitivity, or both. ${ }^{34}$ A study of nondiabetic co-twins of patients with non-insulin dependent diabetes, $\triangle$ shortly before they also developed the disease, suggested that noninsulin dependent diabetes was preceded by detectable metabolico abnormalities; these changes included an impaired insulin response to oral glucose challenge, which therefore may be an early marker for the disease. ${ }^{5}$

This study aimed at showing whether similar metabolic abnor-o malities could be found in the young, apparently normal offspringo of non-insulin dependent diabetics.

\section{Patients and methods}

We selected a consecutive series of 13 patients with established noninsulin dependent diabetes attending the diabetic clinic in Newcastle duringo 1982, who fulfilled the following criteria: $(a)$ a sibling also had non-insulin ${ }^{+}$ 
dependent diabetes, $(b)$ their spouses had normal oral glucose tolerance and no family history of diabetes, and $(c)$ all the offspring were aged between 12 and 45 years, were not diabetic, and were available for study.

All 32 offspring were studied. To take account of sib-sib correlations we analysed 13 offspring, each randomly selected from each of the 13 families. This group was compared with suitable controls sought from unrelated friends of the offspring and hospital employees and selected to achieve a similar distribution of age, body mass index, sex, and social class. The offspring and the controls were similar for mean age (31 (SD 9) $v 29(8)$ years), body mass index $\left(26 \cdot 4(3.5) v 24 \cdot 2(2 \cdot 3) \mathrm{kg} / \mathrm{m}^{2}\right)$, sex (six men in each group), and social class (9/13 $v 10 / 13$ from social class III, IV, or V). In addition, we compared all 32 offspring with 18 healthy controls who were of similar age (30 (11) $v 29$ (9) years), body mass index (25.7 (3.9) $v 23.6$ $\left.(2 \cdot 5) \mathrm{kg} / \mathrm{m}^{2}\right)$, sex (17/32 $\left.v 10 / 18 \mathrm{men}\right)$, and social class (19/32 $v 12 / 18$ from social class III, IV, or V). None of the subjects were taking any drug at the time of study and all were eating their usual diet. Both the offspring and the controls lived in Newcastle. None of the subjects had previously had a glucose tolerance test.

After an overnight fast (10-12 hours) an indwelling cannula was inserted into the subjects' antecubital vein under local anaesthesia and kept open with $0 \cdot 15 \mathrm{~mol} / \mathrm{l}$ saline and sodium citrate. After 30 minutes' rest venous blood was taken 15 minutes before and immediately before oral administration of $75 \mathrm{~g}$ glucose in $300 \mathrm{ml}$ water (drunk over four minutes). Further samples were taken at $15,30,60,90$, and 120 minutes. Whole blood was used for estimation of glucose (YSI glucose analyser), serum for radioimmunoassay of insulin and $C$ peptide, plasma for radioimmunoassay of glucagon ${ }^{67}$ and perchloric acid extract for assay of lactate, pyruvate, alanine, glycerol, and 3hydroxybutyrate concentrations by an automated enzymatic fluorometric technique. ${ }^{8}$ Fasting concentrations of haemoglobin $\mathrm{A}_{1}$, serum cholesterol, and urate were also measured. Haemoglobin was measured by an electroendosmosis method (Corning Instruments). Cholesterol and urate concentrations were measured by standard automated enzymatic techniques. Basal concentrations were expressed as the mean of the concentrations at -15 and 0 minutes. Areas under the curve after glucose challenge - that is, above basal concentrations and up to 120 minutes-were calculated using the method of least squares. Mean total concentrations were calculated as the mean of the six concentrations throughout the test including the basal concentrations.

Results are expressed as means and SDs and were compared using two tailed Student's $t$ test for unpaired observations. Results were considered significant at $\mathrm{p}<0.05$, and levels of significance were similar with both the Wilcoxon's rank sum test and Student's $t$ test. The results with Student's $t$ test are presented. All the significant variables approximated normal distribution in that two thirds of the values fell within I SD of their mean.

The study was approved by the Newcastle Health Authority ethical committee, and informed consent was obtained from all subjects.

\section{Results}

\section{FASTING CONCENTRATIONS}

Thirteen offspring (one from each family) had significantly higher concentrations of blood glucose, haemoglobin $A_{1}$, serum insulin, serum $C$ peptide, and plasma glucagon than 13 controls (table I). The $C$ peptide:

TABLE I-Mean $(S D)$ concentrations of glucose, haemoglobin, insulin, $C$ peptide, and glucagon in the offspring and controls

\begin{tabular}{|c|c|c|c|c|c|}
\hline & $\begin{array}{c}\text { Offspring } \\
(n=13)\end{array}$ & $\begin{array}{c}\text { Controls } \\
(n=13)\end{array}$ & $\begin{array}{c}\text { Mean } \\
\text { difference }\end{array}$ & $\begin{array}{l}\text { Confidence } \\
\text { intervals }\end{array}$ & Significance \\
\hline \multicolumn{6}{|l|}{ Glucose $(\mathrm{mmol} / \mathrm{l})$} \\
\hline Fasting & $5.3(0.8)$ & $4.8(0.6)$ & 0.5 & 0.43 to 0.57 & $<0.05$ \\
\hline After oral glucose & $215(96)$ & $129(95)$ & 86 & 8 to 164 & \\
\hline Total & $6 \cdot 7(1 \cdot 0)$ & $5 \cdot 7(0.9)$ & $1 \cdot 0$ & 0.3 to 1.7 & $<0.01$ \\
\hline Haemoglobin $\mathbf{A}_{1}$ (\%) & $7 \cdot 8(2 \cdot 11)$ & $6.9(0.9)$ & 0.9 & 0.19 to 1.61 & $<0.05$ \\
\hline \multicolumn{6}{|l|}{ Insulin $(\mathrm{pmol} / \mathrm{l})$} \\
\hline Fasting & $126(50)$ & $54(15)$ & 72 & 42 to 102 & $<0.01$ \\
\hline After oral glucose & $32780(16970)$ & $24040(6630)$ & & & $<0.06$ \\
\hline Total & $286(148)$ & $200(55)$ & 86 & 70 to 178 & $<0.06$ \\
\hline \multicolumn{6}{|l|}{ C peptide (nmol/l) } \\
\hline Fasting & $0.41(0.17)$ & $0 \cdot 28(0 \cdot 10)$ & $0 \cdot 13$ & 0.02 to 0.24 & $<0.05$ \\
\hline After oral glucose & $127(18)$ & $98(26)$ & 29 & 22 to 36 & $<0.01$ \\
\hline Total & $0.86(0.11)$ & $0.67(0 \cdot 19)$ & $0 \cdot 19$ & 0.07 to 0.31 & $<0.01$ \\
\hline \multicolumn{6}{|l|}{ Glucagon (pmol/l) } \\
\hline Fasting & $12 \cdot 1(2 \cdot 9)$ & $6 \cdot 0(2 \cdot 6)$ & $6 \cdot 1$ & $3 \cdot 7$ to $8 \cdot 3$ & $<0.01$ \\
\hline After oral glucose & $8.9(4)$ & $5 \cdot 7(4 \cdot 6)$ & & & NS \\
\hline Total & $11 \cdot 2(3 \cdot 2)$ & $7 \cdot 8(4)$ & $3 \cdot 4$ & 0.6 to 6.3 & $<0.05$ \\
\hline
\end{tabular}

Conversion: SI to traditional units_Glucose: $1 \mathrm{mmol} / \mathrm{l}=18 \mathrm{mg} / 100 \mathrm{ml}$. Insulin: $1 \mathrm{pmol} / \mathrm{l}=$ $0 \cdot 1394 \mathrm{mU} / \mathrm{l}$. insulin molar ratio was similar in the offspring $(4 \cdot 3(2 \cdot 2))$ and the controls $(5 \cdot 6(2 \cdot 3))$. These offspring had higher concentrations of blood lactate but not of pyruvate, glycerol, alanine, 3-hydroxybutyrate, serum urate, or cholesterol (see table III).

These differences were confirmed in all 32 offspring, who had higher mean concentrations than their 18 controls of blood glucose, haemoglobin $A_{1}$, serum insulin, serum $C$ peptide, and plasma glucagon (table II). The mean $C$ peptide:insulin molar ratio was similar in the offspring $(4.5(2 \cdot 3))$ and the controls $(5 \cdot 5(2 \cdot 3))$. The 32 offspring also had higher mean concentrations of blood lactate (table III).

TABLE II-Mean concentrations of glucose, haemoglobin, insulin, $C$ peptide, and glucagon in the offspring and controls

\begin{tabular}{|c|c|c|c|c|}
\hline & $\begin{array}{c}\text { Offspring } \\
(\mathrm{n}=32)\end{array}$ & $\begin{array}{c}\text { Controls } \\
(n=18)\end{array}$ & $\begin{array}{c}\text { Mean } \\
\text { difference }\end{array}$ & $\begin{array}{l}\text { Confidence } \\
\text { intervals }\end{array}$ \\
\hline \multicolumn{5}{|l|}{ Glucose $(\mathrm{mmol} / \mathrm{l})$} \\
\hline Fasting & $5 \cdot 3$ & $4 \cdot 7$ & 0.6 & 0.16 to 1.04 \\
\hline After oral glucose & 212 & 126 & 86 & 27 to 145 \\
\hline Total & 6.6 & $5 \cdot 2$ & 1.4 & 0.8 to 2.0 \\
\hline Haemoglobin $A_{1}(\%)$ & $8 \cdot 4$ & $7 \cdot 0$ & $1 \cdot 4$ & -0.15 to 1.95 \\
\hline \multicolumn{5}{|l|}{ Insulin (pmol/l) } \\
\hline Fasting & 104 & 60 & 44 & 14 to 73 \\
\hline After oral glucose & 42200 & 31100 & 11100 & 60 to 22210 \\
\hline Total & 228 & 205 & 83 & 8 to 159 \\
\hline \multicolumn{5}{|l|}{ C peptide $(\mathrm{nmol} / \mathrm{l})$} \\
\hline Fasting & 0.41 & 0.27 & $0 \cdot 14$ & 0.053 to 0.227 \\
\hline After oral glucose & 118 & 96 & 22 & $7 \cdot 9$ to $36 \cdot 1$ \\
\hline Total & $0 \cdot 82$ & 0.65 & $0 \cdot 17$ & 0.08 to 0.26 \\
\hline \multicolumn{5}{|l|}{ Glucagon $(\mathrm{pmol} / \mathrm{l})$} \\
\hline Fasting & $15 \cdot 5$ & 8.9 & $6 \cdot 6$ & $2 \cdot 1$ to $11 \cdot 1$ \\
\hline After oral glucose & $8 \cdot 6$ & $5 \cdot 7$ & & \\
\hline Total & $11 \cdot 2$ & 6.9 & $4 \cdot 3$ & 1.7 to 6.9 \\
\hline
\end{tabular}

Conversion: SI to traditional units_Glucose: $1 \mathrm{mmol} / \mathrm{l}=18 \mathrm{mg} / 100 \mathrm{ml}$. Insulin: $1 \mathrm{pmol} / \mathrm{l}=$ $0 \cdot 1394 \mathrm{mU} / \mathrm{l}$.

TABLE III-Mean (SD) fasting and total concentrations after oral glucose of metabolites, urate, and cholesterol in group 1 (13 sibs and controls) and group 2 (32 offspring and 18 controls)

\begin{tabular}{|c|c|c|c|c|}
\hline & \multicolumn{2}{|c|}{ Group 1} & \multicolumn{2}{|c|}{ Group 2} \\
\hline & Siblings & Controls & Siblings & Controls \\
\hline \multicolumn{5}{|c|}{ Lactate $(\mathrm{mmol} / \mathrm{l})$} \\
\hline Fasting & $0.85(0.35)$ & $0.65(0.20)$ & $0.97(0.40)$ & $0.51(0.29)$ \\
\hline Total & $1.15(0.38)$ & $0.84(0.22)^{\star}$ & $1 \cdot 17 \quad(0 \cdot 40)$ & $0.85(0.20)$ \\
\hline \multicolumn{5}{|c|}{ Pyruvate $(\mathrm{mmol} / \mathrm{l})$} \\
\hline Fasting & $0.071(0.031)$ & $0.055(0.011)$ & $0.076(0.029)$ & $0.045(0.025)$ \\
\hline Total & $0.094(0.048)$ & $0.071(0.011)^{\star}$ & $0.095(0.039)$ & $0.071(0.011)$ \\
\hline \multicolumn{5}{|c|}{ Glycerol (mmol/l) } \\
\hline Fasting & $0.048(0.011)$ & $0.058(0.04)$ & $0.062(0.02)$ & $0.061(0.040)$ \\
\hline Total & $0.043(0.012)$ & $0.044(0.030)$ & $0.048(0.018)$ & $0.046(0.029)$ \\
\hline \multicolumn{5}{|c|}{ Alanine (mmol/l) } \\
\hline Fasting & $0.28(0.08)$ & $0.25(0.07)$ & $0.31(0.08)$ & $0.22(0.07)$ \\
\hline Total & $0.30(0.08)$ & $0.26(0.06)$ & $0.31(0.08)$ & $0.28 \quad(0.08)$ \\
\hline \multicolumn{5}{|c|}{ 3-Hydroxybutyrate $(\mathrm{mmol} / 1)$} \\
\hline Fasting & $0.05(0.05)$ & $0.085(0.079)$ & $0.079(0.07)$ & $0.066(0.07)$ \\
\hline Total & $0.05(0.05)$ & $0.071(0.063)$ & $0.046(0.06)$ & $0.046(0.05)$ \\
\hline \multicolumn{5}{|c|}{ Urate $(\mathrm{mmol} / \mathrm{l})$} \\
\hline $\begin{array}{l}\text { Fasting } \\
\text { Total }\end{array}$ & $0.27(0.05)$ & $0 \cdot 30(0 \cdot 07)$ & $0.28(0.06)$ & $0.30(0.07)$ \\
\hline \multicolumn{5}{|c|}{ Cholesterol $(\mathrm{mmol} / \mathrm{l})$} \\
\hline $\begin{array}{l}\text { Fasting } \\
\text { Total }\end{array}$ & $5.0 \quad(0.9)$ & $4.9 \quad(0.8)$ & $5 \cdot 1 \quad(1 \cdot 1)$ & $(0 \cdot 8)$ \\
\hline
\end{tabular}

${ }^{\star} \mathrm{p}<0.05$ For differences between sibs and controls in group 1 .

Conversion: SI to traditional units-Lactate: $1 \mathrm{mmol} / \mathrm{l}=9 \mathrm{mg} / 100 \mathrm{ml}$. Pyruvate: $1 \mathrm{mmol} / \mathrm{l}=9$ $\mathrm{mg} / 100 \mathrm{ml}$. Urate: $1 \mathrm{mmol} / \mathrm{l}=16 \cdot 8 \mathrm{mg} / 100 \mathrm{ml}$. Cholesterol $1 \mathrm{mmol} / \mathrm{l}=6 \cdot 4 \mathrm{mg} / 100 \mathrm{ml}$.

\section{RESPONSE TO ORAL GLUCOSE}

At 120 minutes after taking oral glucose the 13 offspring (one from each family) had greater increases than the 13 controls in blood glucose, serum $C$ peptide, and serum insulin. Plasma glucagon was suppressed to a similar degree in the offspring and controls at 120 minutes (see table I).

All 32 offspring also had greater responses than 18 controls in blood glucose concentration, serum insulin, and $\mathrm{C}$ peptide at 120 minutes. Twelve out of 32 offspring showed impaired glucose tolerance with two hourly glucose values greater than $6.7 \mathrm{mmol} / \mathrm{l}(120 \mathrm{mg} / 100 \mathrm{ml})$, of which seven had two hourly values of $7 \mathrm{mmol} / 1(126 \mathrm{mg} / 100 \mathrm{ml})$ or more. Plasma glucagon was suppressed to a similar degree in the 32 offspring and controls at 120 minutes $(8 \cdot 6$ (4) $v 5 \cdot 7(4 \cdot 6 \mathrm{pmol} / \mathrm{l})$. 


\section{TOTAL CONCENTRATIONS}

The 13 offspring had higher mean total concentrations of blood glucose, serum insulin, $\mathrm{C}$ peptide, plasma glucagon, blood lactate, and blood pyruvate. These differences were maintained in all 32 offspring, who had higher mean total values than their 18 controls of blood glucose, serum insulin, serum $\mathrm{C}$ peptide, plasma glucagon, blood lactate, and blood pyruvate (see tables II and III).

All the results in the offspring both when fasting and after the oral glucose load were unimodally distributed. Bimodality could not be excluded, however, owing to the limited number of patients studied. Glucose values (fasting, response, or mean total) did not correlate significantly (using the correlation coefficient $r$ ) with age or body mass index in the offspring (either the selected 13 or all 32 ) or the controls (either the selected 13 or all 18). A similar analysis for the other factors also showed no significant correlationthat is, for insulin, $C$ peptide, glucagon, lactate, pyruvate, glycerol, alanine, 3-hydroxybutyrate, haemoglobin $A_{1}$, urate, or cholesterol.

\section{Discussion}

These results indicate that young offspring of selected noninsulin dependent diabetics may show extensive metabolic changes including impaired glucose tolerance. A group of 13 offspring, one randomly selected from each family, had increased concentrations of glucose, lactate, insulin, and glucagon, and these differences were maintained in all 32 offspring from the 13 families studied.

There are no comparable studies of the offspring of non-insulin dependent diabetics. Previous studies have been performed on either the offspring of conjugal diabetics with an undefined type of diabetes $^{910}$ or subjects who belonged to ethnic groups with an extraordinarily high prevalence of diabetes. ${ }^{112}$ In addition, most studies of offspring did not include a control group of similar age, sex, and weight. ${ }^{13}$ The offspring we tested had as a group higher concentrations of glucose and lactate than controls both when fasting and after an oral glucose load. As concentrations of haemoglobin $A_{1}$ were higher in the offspring these changes were likely to be long standing and not the result of the stress of the study. The 3-hydroxybutyrate concentrations were normal, which suggests that the action of insulin in the offspring was sufficient to suppress hepatic ketogenesis but not adequate to maintain normal intermediary metabolism.

The hyperglycaemia in the offspring could not be ascribed to obesity as the controls were of similar weight; furthermore, within this group there was no correlation between glucose tolerance and obesity. The insulin concentration in the offspring was raised, particularly when fasting. The hyperinsulinaemia could have been due to an increase in secretion or a decrease in clearance of the hormone. An increase in insulin secretion is likely as C peptide concentrations were also raised throughout the study. This increased secretion may simply be secondary to hyperglycaemia or it might reflect insulin resistance. This present study was not designed to assess insulin sensitivity. We do not believe that the hyperinsulinaemia is due to decreased insulin clearance. In particular, hepatic extraction of insulin, a major route of insulin clearance, was normal in the offspring as determined by the $\mathrm{C}$ peptide: insulin molar ratio. This ratio must be interpreted cautiously but it does serve as an index of hepatic insulin extraction because the hormones are secreted in equimolar amount, but only insulin is extracted by the liver. ${ }^{14}$

Non-insulin dependent diabetics have increased concentrations of glucagon both when fasting and after an oral glucose load. ${ }^{15}$ These changes are similar to those we found in the offspring. The hyperglucagonaemia might be either the cause or the consequence of the hyperglycaemia. It seems likely, however, that hyperglucagonaemia contributed, at least partly, to the hyperglycaemia in the offspring as both hyperglycaemia and hyperinsulinaemia usually reduce glucagon secretion. ${ }^{16}$

We have shown, to our knowledge for the first time, that young offspring of selected non-insulin dependent diabetics may have extensive metabolic changes. These changes include impaired glucose tolerance and, in contrast to what we expected, are associated with both hyperinsulinaemia and hyperglucagonaemia.

We thank the Wellcome Trust, the British Diabetic Association, and Novo Ltd for supporting this work, and Dr Hodson, Ms L Ashworth, and the staff of the Department of Clinical Biochemistry, Royal Victoria Infirmary, and University of Newcastle upon Tyne for help with assays.

\section{References}

1 Barnett AH, Eff C, Leslie RDG, Pyke DA. Diabetes in identical twins. Diabetologia 1981;20:87-93.

2 Gepts W, Le Compte PM. The pancreatic islets in diabetes. Am f Med 1981;70:105-15.

3 Kolterman OG, Gray RS, Griffin J, et al. Receptor and post-receptor defects contribute to the insulin resistance in non-insulin dependent diabetes mellitus. 7 Clin Invest 1981;68:957-69.

4 Pfeifer MA, Halter JB, Porte D. Insulin secretion in diabetes mellitus. Am 7 Med 1981;70:579-88.

5 Barnett AH, Spiliopoulos AJ, Pyke DA, Stubbs WA, Burrin J, Alberti KGMM Metabolic studies in unaffected co-twins of non-insulin-dependent diabetics. $\mathrm{Br} \mathrm{Med} \mathcal{F}$ 1981;282:1656-8.

6 Soeldner J, Slone D. Critical variables in radioimmunoassay of serum insulin using the double antibody techniques. Diabetes 1965;14:771-9.

7 Orskov $\mathrm{H}$, Thomsen HG, Yde $\mathrm{H}$. Wick chromatography for rapid and reliable immunoassay of insulin, glucagon and growth hormone in normal and diabetic humans. 7 Clin Invest 1968;63:849-57.

8 Lloyd B, Burrin J, Smythe P, Alberti KGMM. Enzymatic fluorometric continuous-flow assay for blood glucose, lactate, pyruvate alanine, glycerol and 3-hydroxybutyrate. Clin Chem 1978:24:1724-9.

9 Daweke H, Ruenauer R, Schilling W, et al. Untersuchungen des Kohlenhydrat- und Fettstoffwechsels bei Praediabetes. Diabetologia 1968;4:349-57.

10 Serrano-Rios M, Ramos F, Rodriguez-Minon JL, Vivanco F. Studies in prediabetes. Insulin response to oral glucose, intravenous tolbutamide and rapid intravenous glucose infusion in genetic prediabetics. Diabetologia 1970;6:392-8.

11 Savage PJ, Bennett PH, Gorden P, Miller M. Insulin responses to oral carbohydrate in true prediabetics and matched controls. Lancet $1975 ; \mathrm{i}: 300-2$.

12 Jackson WPU, van Mieghem W, Keller P. Insulin excess as the initial lesion in diabetes. Lancet 1972; i: 1040-4

13 Johansen K, Soeldner JS, Gleason RE. Insulin, growth hormone, and glucagon in prediabetes mellitus-a review. Metabolism 1974;23:1185-99.

14 Polonsky KS, Rubenstein AH. C-peptide as a measure of the secretion and hepatic extraction of insulin. Diabetes 1984:33:486-94.

15 Unger RH, Orci L. Glucagon and the A cell. Physiology and pathophysiology (second of two parts). N Engl ₹ Med 1981;304:1575-80.

16 Unger RH, Orci L. Glucagon and the A cell. Physiology and pathophysiology (first of two parts). N Engl f Med 1981;304:1518-24.

(Accepted I fuly 1986)

100 YEARS AGO

The assertion that the sanitary arrangements of the Charterhouse School a Godalming were not all that they might be was met, when first made, by an indignant, almost reproachful, denial; everything, it was more than hinted, that a paternal governing body could do had been done, and to suggest that the drainage might be defective was really shocking ingratitude. People, however, who are disposed to believe that there is no effect without a cause were content to await the result of the enquiry by the Local Government Board before forming any definite opinion. Even before this report is ready, however, the action of the governing body itself proves that it is conscious of a serious flaw in its arrangements. When the ground at Godalming was bought, not enough was acquired for the erection of masters'-houses, which, consequently, were built on adjoining plots of about an acre, or an acre and ahalf, in extent. In these houses, the solid excreta are treated on the dry system, but all the slop-water had to be got rid of in some other way; subirrigation has been tried, but, as each house contains from sixty to seventy persons, has failed. The masters and the governing body have been at loggerheads with the local sanitary authority for years, and have only within the last fortnight come to terms by conceding what the sanitary authority proposed long ago. The Charterhouse is to provide and maintain a sewer, with the necessary outfall, at their own cost, and the rural sanitary authority agree to accept the sewer. The parent, however, who first called public attention to the presence of an epidemic of diphtheria in the school, and withdrew his son from an area which the head-master and governing body now, by their action, admit is in an unsanitary condition, is punished by the refusal to receive his son back. This may be good discipline, but it is very doubtful justice. (British Medical fournal 1886;ii:379.) 